\title{
ANALISIS PENGARUH MOTIVASI DAN DISIPLIN KERJA TERHADAP KINERJA GURU SMK DHARMA WANITA GRESIK
}

\author{
${ }^{1)}$ Nur Cahyadi, ${ }^{2)}$ Noviatul Rochmah \\ 1) 2)Universitas Muhammadiyah Gresik \\ 1) nurcahyadi@umg.ac.id, ${ }^{2}$ noviatul rochmah@umg.ac.id
}

\begin{abstract}
ABSTRAK
Seiring dengan perkembangan zaman, pendidikan merupakan salah satu kebutuhan sangat penting dalam kehidupan saat ini yang harus dipenuhi oleh manusia. Tingkat Pendidikan menjadi tolak ukur untuk kemajuan suatu wilayah, daerah ataupun negara. Tujuan dalam penelitian ini adalah untuk menganalisis pengaruh motivasi dan disiplin kerja terhadap kinerja guru SMK Dharma Wanita Gresik. Metode penelitian yang digunakan adalah metode penelitian kuantitatif ekploraitf, dengan menggunakan teknik analisis Regresi Linear Berganda. Populasi dalam penelitian ini adalah seluruh guru SMK Dharma Wanita yaitu sebanyak 34 orang, dengan teknik penentuan sampel adalah sampling jenuh sehingga didapatkan jumlah sampel sebanyak 34 orang. Hasil penelitian ini menunjukkan bahwa secara parsial variabel motivasi $\left(X_{1}\right)$ mampu meningkatkan kinerja $(\mathrm{Y})$, begitu juga dengan variabel disiplin kerja $\left(\mathrm{X}_{2}\right)$ didapatkan hasil mampu meningkatkan kinerja $(Y)$ guru. Hal ini dapat dilihat dari hasil pengolahan data menggunakan SPSS versi 26.0 pada uji t didapatkan nilai probabilitas signifikansi untuk motivasi sebesar 0.000 dengan nilai beta (B) sebesar 0.659 , sedangkan nilai probabilitas signifikansi untuk disiplin kerja adalah 0,001 dengan nilai beta (B) sebesar 0,408. Sedangkan untuk nilai signifikansi uji simultan (Uji F) didapatkan nilai signifikansi sebesar 0,000, dimana nilai signifikansi tersebut kurang dari 0,05 , sehingga dapat disimpulan bahwa secara simultan variable motivasi dan disiplin kerja berpengaruh signifikan terhadap kinerja guru SMK Dharma Wanita Gresik. Dari hasil tersebut dinyatakan bahwa baik secara parsial (uji t) maupun secara simultan (uji F) menyatakan bahwa variable motivasi dan disiplin kerja mempunyai pengaruh secara signifikan terhadap kinerja guru.
\end{abstract}

Kata Kunci : Motivasi, Disiplin Kerja, Kinerja

\begin{abstract}
Along with the times, education is one of the very important needs in life today that must be fulfilled by humans. Education level becomes a benchmark for the progress of a region, region or country. The purpose of this study was to analyze the effect of motivation and work discipline on the performance of Gresik Vocational School teachers. The research method used is a quantitative quantitative research method, using multiple linear regression analysis techniques. The population in this study were all 34 Dharma Wanita Vocational School teachers, with the sampling technique being saturated sampling so as to obtain a total sample of 34 people. The results of this study indicate that partially motivation variables $(X 1)$ can improve performance $(Y)$, as well as work discipline variables (X2), the results are able to improve teacher performance $(Y)$. This can be seen from the results of data processing using SPSS version 26.0 in the $t$ test, the significance probability value for motivation is 0.000 with a beta value (B) of 0.659 , while the probability value of significance for work discipline is 0.001 with a beta value $(B)$ of 0.408 .
\end{abstract}




\section{Vol : 5 Nomor : 2 September 2020}

While for the significance value of the simultaneous test (Test F) obtained a significance value of 0,000, where the significance value is less than 0.05 , so it can be concluded that simultaneously the motivation and work discipline variables significantly influence the performance of Gresik Vocational School SMK teachers. From these results it is stated that both partially (t test) and simultaneously ( $F$ test) states that the motivation and work discipline variables have a significant influence on teacher performance.

Keywords: Motivation, Work Discipline, Performance

\section{A. Latar Belakang}

Seiring dengan perkembangan zaman, pendidikan merupakan salah satu kebutuhan sangat penting dalam kehidupan saat ini yang harus dipenuhi oleh manusia. Tingkat Pendidikan menjadi tolak ukur untuk kemajuan suatu wilayah, daerah ataupun negara. Pencapaian tujuan suatu organisasi menunjukkan suatu hasil kerja atau prestasi kerja dalam organisasi sebagai kinerja atau performa organisasi. Guru merupakan seoarang pendidik professional yang tugasnya mendidik, mengajar, membimbing, mengarahkan, melatih, menilai dan mengevaluasi peserta didik yang berkaitan dengan upaya dalam mencerdaskan kehidupan bangsa melalui jalur pendidikan formal pada jenjang pendidikan dasar maupun menengah. Guru diharapkan memiliki kinerja yang baik agar pelaksanaan Pendidikan dapat terlaksana dan berjalan dengan baik. Tetapi pada kenyataannya masih ada guru yang belum menunjukan kinerja yang professional. Pada proses pembelajaran masih terdapat guru yang tidak disiplin dalam bekerja, masih kurangnya semangat guru dalam bekerja karena kurangnya motivasi dari pimpinan atau kepala sekolah. Faktor lain yang mempengaruhi kinerja guru salah satunya adalah berasal dari dalam individu seperti motivasi, kompetensi dan juga Pendidikan. Motivasi dari pimpinan dalah hal ini adalah kepala sekolah sangat dibutuhkan oleh guru dalam menjalankan kinerja guru agar lebih giat lagi, karena kepala sekolah bukan hanya sebagai educator, supervisor, leader juga diharapkan sebagai motivator untuk guru.

SMK Dharma Wanita Gresii merupakan salah satu sekolah kejuruan yang berlokasi di Gresik, berdiri pada tahun 1977 dibawah naungan Yayasan Pendidikan Dharma Wanita Kabupaten Gresik yang siap mencetak tenaga terampil di program keahlian tata boga, tata busana, tata kecantikan, Teknik komputer dan informatika. Dari hasil survey awal yang dilakukan sebagai latar belakang dalam penelitian ini adalah terdapat guru yang tidak masuk kerja tanpa keterangan, terdapat guru yang cuti bekerja, dan masih terdapat guru yang datang terlambat dalam bekerja. Ketidakhadiran dan keterlambatan guru dapat 


\section{Vol : 5 Nomor : 2 September 2020}

dijadikan sebagai salah satu faktor dalam menurunya kinerja guru. Dari hasil survei awal didapatkan data dari 34 guru SMK Dharma Wanita sebagai berikut :

Tabel 1. Survey Awal Disiplin Kerja

\begin{tabular}{|l|c|c|}
\hline \multicolumn{1}{|c|}{ Uraian } & Jumlah Guru & Persentase (\%) \\
\hline Tidak masuk kerja (ljin) & 9 & 26,47 \\
\hline Tidak masuk kerja tanpa keterangan & 7 & 20,59 \\
\hline Cuti Kerja & 2 & 5,88 \\
\hline Datang terlambat & 15 & 44,12 \\
\hline Terlambat masuk kelas & 10 & 29,41 \\
\hline Mengakhir pelajaran lebih awal & 8 & 23,53 \\
\hline
\end{tabular}

Sumber : Data sekunder (bulan Januari-Maret 2020)

Dari data yang didapatkan tersebut dapat diberikan penjelasan bahwa guru yang tidak hadir ataupun yang terlambat dalam bekerja maka tugas yang sudah diberikan akan terbengkalai atau tidak dapat diselesaikan tepat waktu sesuai dengan waktu yang diharapkan, sehingga dapat katakana bahwa terdapat penurunan kinerja guru. Disinilah peran pimpinan sangat dibutuhkan untuk memberikan ketegasan dan memberikan motivasi kepada guru untuk dapat meningkatkan kinerja. Pemberian motivasi tidaklah mudah karena pimpinan atau kepala sekolah harus mengetahui kebutuhan dan keinginan guru untuk dapat melaksanakan kegiatannya sampai menghasilkan kinerja yang diinginkan. Motivasi tidak dapat begitu saya muncul dari diri seseorang tetapi dari kekuatan yang ada di lingkungan sekitar. Motivasi menurut Sobri, dkk (2009) adalah suatu kekuatan yang dapat mendorong seseorang agar dapat melakukan suatu kegiatan. Motivasi mampu mempengaruhi prestasi guru untuk meningkatkan kinerja guru dalam mencapai tujuan Pendidikan.

Berdasarkan dengan data yang sudah didapatkan dari hasil survey awal tersebut di atas maka peneliti bertujuan untuk mengetahui dan menganalisis baik secara parsial maupun simultan besarnya pengaruh dari variabel kepemimpinan, motivasi, dan disiplin kerja terhadap kinerja guru SMK Dharma Wanita Gresik

\section{B. Tinjauan Pustaka}

1. Motivasi

Motivasi merupakan suatu kondisi atau energi yang dapat menggerakkan seseorang yang terarah untuk mencapai tujuan organisasi. Motivasi tidak muncul begitu saja pada diri seseorang, melainkan terbentuk dari sikap (attitude) dalam menghadapi kondisi situasi kerja di suatu tempat (situation). Menurut Heller dalam 


\section{Vol : 5 Nomor : 2 September 2020}

buku Wibowo (2016) menyatakan bahwa motivasi adalah keinginan untuk bertindak. Ada juga yang berpendapat, motivasi harus didukung dari luar, tetapi saat ini semakin dipahami bahwa setiap orang akan termotivasi oleh kekuatan yang berbeda. Pencapaian tujuan atau goal-directed behavior dalam buku Wibowo (2016) menyatakan motivasi merupakan proses psikologi yang dapat membangkitkan serta mengarahkan perilaku untuk pencapaian tujuan yang diinginkan.

Lain halnya yang diungkapkan oleh Robbins dalam bku Wibowo (2016) motivasi sebagai proses yang dapat menyebabkan intensitas (intensity), arah (direction), dan usaha terus menerus (persistence) seorang individu untk menuju pencapaian tujuan. Dalam hal ini intensitas mengarah seberapa keras seseorang dalam berusaha. Motivasi terdapat dimensi usaha yang dilakukan terus menerus. Sementara itu motivasi menurut Greenberg dan Baron dalam buku Wibowo (2016) merupakan serangkaian proses yang dapat membangkitkan (arouse), mengarahkan (direct), dan menjaga (maintain) perilaku manusia untuk menuju pencapaian tujuan.

Indikator motivasi menurut Abraham Maslow dalam buku Edison (2016) adalah sebagai berikut :

1. Kebutuhan fisiologis

2. Kebutuhan rasa aman

3. Kebutuhan untuk disukai

4. Kebutuhan harga diri

5. Kebutuhan pengembangan diri

2. Disiplin Kerja

Dalam kehidupan sehari-hari dibutuhkan peraturan dan ketentuan yang dapat mengatur serta membatasi setiap kegiatan atau perilakunya. Hal ini dibutuhkan karena manusia sebagai invidu kadang kalanya berkeinginan hidup bebas, melepaskan diri dari ikatan dan peraturan yang telah membatasi kegiatannya dan perilakunya. Penyesuaikan diri setiap individu terhadap sesuatu yang telah ditetapkan kepadanya, akan dapat menciptakan masyarakat yang tertib dan bebas dari kekacauan. Begitu pula dengan kehidupan dalam suatu organisasi akan sangat dibutuhkan ketaatan dari setiap anggotanya terhadap peraturan dan ketentuan yang telah berlaku pada organisasi tersebut. Sehingga disiplin kerja sangatlah dibutuhkan untuk mencapai tujuan suatu organisasi. Elemen penting yang mempengaruhi kinerja guru salah 


\section{Vol : 5 Nomor : 2 September 2020}

satunya adalah disiplin kerja. Disiplin kerja merupaan suatu alat yang dapat digunakan oleh pimpinan sebagai prosedur dalam mengkoreksi atau menghukum bawahannya jika melanggar peraturan. Penegakan disiplin kerja dapat memperkuta pengaruh prilaku kerja dan mengatasi masalah kinerja yang buruk serta dapat meningkatkan kinerja. Masalah akan dapat teratasi secara cepat dan mudah jika disiplin kerja dilaksanakan secara baik serta tidak menunda waktu.

Disiplin kerja menurut Singodimedjo dalam buku Eddy Sutrisno 92017) menyatakan bahwa disiplin merupakan sikap kesediaan dan kerelaan seseorang untuk dapat mematuhi dan mentaati normal-normal peraturan yang berlaku di sekitarnya. Jika disiplin guru dilaksanakan dengan baik maka akan dapat mempercepat tujuan Pendidikan, sedangkan jika disiplin kerja telah merosot maka akan menjadikan penghalang atau memperlambat dalam pencapaian tujuan Pendidikan. Disiplin kerja dapat dijadikan sebagai alat penggerak agar setiap pekerjaan dapat berjalan dengan lancar. Disiplin kerja dapat menjamin terpeliharanya tata tertib dalam suatu organisasi sehingga pelaksanaan tugas berjalan dengan baik.

Menurut Edy Sutrisno (2016) menyatakan terdapat 4 indikator yang mempengaruhi disiplin kerja dalam suatu organisasi diantaranya yaitu :

1. Taat terhadap aturan waktu

2. Taat terhadap peraturan organisasi

3. Taat terhadap aturan dan perilaku dalam pekerjaan

4. Taat terhadap peraturan lain yang ada diperusahaan.

3. Kinerja

Kualitas manajemen kinerja sebagai driven force (kekuatan pendorong) yang mampu memberikan percepatan dalam perkembangan dan kemajuan suatu organisasi. Proses pelaksanaan aktivitas harus dilakukan monitoring, penilian, dan review atau peninjauan ulang kinerja yang dilakukan oleh sumber daya manusia. Pada kegiatan monitoring, dapat dilakukan pengukuran dan penilaian kinerja secara periodik agar dapat mengetahui pencapaian kemajuan kinerja yang telah dilakukan. Kinerja dapat diukur dan diketahui pada saat individua tau sekelompok mempunyai kriteria atau standar keberhasilan sebagai tolak ukur yang ditetapikan oleh organisasi. Sebaliknya jika tidak ada tolak ukur keberhasilan yang ditetapkan oleh organisasi maka tidak mungkin dapat diketahui kinerja organisasi. 


\section{Vol : 5 Nomor : 2 September 2020}

Kinerja menurut Colquitt, LePine, dan Wesson dalam buku Wibowo (2016) adalah nilai serangkaian perilaku seorang pekerja yang memberikan kontribusi secara positif maupun negatif pada penyelesaian tujuan suatu organisasi. Menurut Chaizi Nasucha alam buku Fahmi (2016) menyatakan bahwa kinerja organisasi sebagai efektivitas organisasi secara menyeluruh untuk pemenuhan kebutuhan yang telah ditetapkan setiap kelompok yang berkenaan dengan usaha yang sistematik dan meningkatkan kemampuan organisasi terus menerus untuk mencapai kebutuhan secara efektif. Kinerja suatu organisasi dilakukan segenap sumber daya manusia dalam suatu organisasi, baik dari unsur pemimpin maupun pekerja, tetapi organisasi tidak hanya dipengaruhi oleh sumber daya manusia saja didalamnya tetapi juga dipengaruhi oleh sumber daya lainnya seperti halnya dana, bahan, peralatan, teknologi, serta mekanisme kerja yang berlangsung didalam suatu organisasi.

Penilaian kinerja sangat penting dilakukan oleh organisasi, hal ini juga dibutuhkan oleh pegawai/karyawan/guru yang membutuhkan umpan balik (feedback) yang digunakan untuk perbaikan dan peningkatan kinerja agar lebih baik lagi. Tujuan dilakukan penelitian kinerja adalah untuk mengetahui sejauh mana perubahan kinerja yang telah terjadi, sehingga karena begitu pentingnya penilaian ini maka dapat dilakukan secara berkelanjutan. Menurut Emron Edison, Yohni Anwar, Imas Komariyah (2016) indicator kinerja sebagai berikkut :
1. Target
2. Kualitas
3. Wakut
4. Taat asas

\section{Metode Penelitian}

Jenis penelitian yang digunakan panelitian ini adalah penelitian kuantitatif eksploratif yang bertujuan untuk dapat memperdalam pengetahuan dan mencari ide baru mengenai gejala yang berkaitan dengan motivasi, disiplin kerja dan kinerja. Teknik pengumpulan data menggunakan pengamatan melalui kuesioner dan hasil penelitian cenderung untuk digeneralisasikan. Variabel penelitian diantaranya yaitu Motivasi $\left(X_{1}\right)$ dan Disiplin Kerja $\left(X_{2}\right)$ dimana kedua variabel tersebut sebagai variabel bebas (independent variable), sedangkan variabel kinerja (Y) sebagai variabel terikat (dependent variable). Populasi dalam penelitian ini adalah seluruh guru yang ada di lingkungan SMK Dharma Wanita Gresik yang berjumlah sebanyak 34 orang, sehingga teknik sampling yang digunakan adalah sampling 


\section{Vol : 5 Nomor : 2 September 2020}

jenuh atau total sampling yang artinya seluruh populasi dijadikan sebagai sampel yaitu sebanyak 34 responden. Untuk mengetahui apakah item-item yang tercantum di kuesioner benar-benar dapat mengungkapkan dengan pasti apa yang akan diteliti maka perlu dilakukan uji validitas dan untuk mengetahui adanya konsistensi alat ukur tersebut dalam penggunaannya, dengan kata lain instrumen tersebut mempunyai hasil yang konsisten jika digunakan berulang pada waktu yang berbeda-beda maka dilakukanlah uji reliabilitas.

Berdasarkan teori-teori yang telah dikemukanan di atas, kerangka konseptual pengaruh motivasi dan disiplin kerja terhadap kinerja dapat digambarkan sebagai berikut :

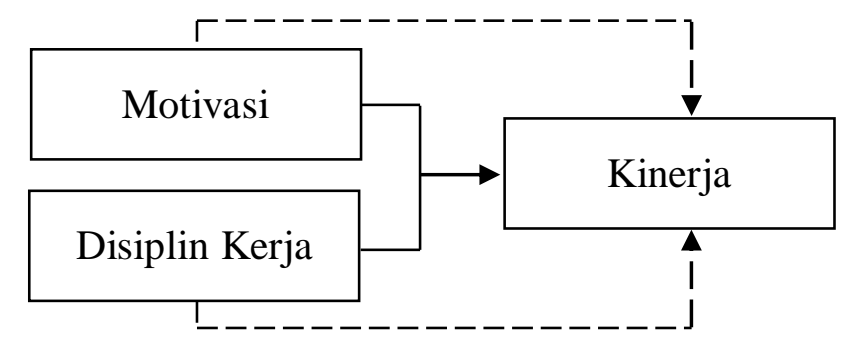

Keterangan :

Gambar 1 Kerangka Konseptual

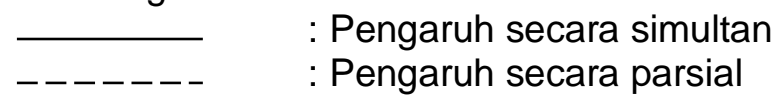

Sebagai uji prasyarat analisis menggunakan model regresi linear berganda maka diperlukan uji asumsi klasik yang digunakan sebelum melanjutkan ke pengujian hipotesis. Pada penelitian ini uji asumsi klasik yang digunakan adalah uji normalitas, uji heteroskedastisitas dan uji multikolinearitas. Teknik analisis data menggunakan teknik uji statistic melalui alat bantu program SPSS Version 26.0 for Windows. Model analisis data yang digunakan dalam penelitian ini adalah Regresi Linear Berganda dimana model ini bertujuan untuk mengetahui pengaruh antara variabel motivasi dan disiplin kerja terhadap kinerja guru SMK Dharma Wanita Gresik.

\section{Hasil Penelitian}

1. Deskripsi Karakteristik Responden

Pada penelitian ini mengangkat permasalahan mengenai pengaruh motivasi dan disiplin kerja terhadap kinerja guru SMK Dharma Wanita Gresik. Responden yang digunakan sebanyak 34 responden, dimana responden telah melakukan pengisian kuesioner yang kemudian dilakukan identifikasi berdasarkan usia, jenis kelamin, Pendidikan terakhir dan masa kerja. Identifikasi ini dilakukan untuk mengetahui karakteristik secara umum responden penelitian. Table berikut merupakan data 
responden yang sudah didapatkan berdasarkan karakteristik usia, jenis kelamin, Pendidikan terakhir dan masa kerja.

Tabel 1 Karakteristik Responden

\begin{tabular}{ccc}
\hline \multicolumn{1}{c}{ Jenis } & $\mathrm{N}$ & $\%$ \\
\hline Jenis Kelamin & & \\
Laki-Laki & 10 & 29,4 \\
Perempuan & 24 & 70,6 \\
Total & $\mathbf{3 4}$ & $\mathbf{1 0 0}$ \\
Usia & & \\
21-30 tahun & 1 & 2,9 \\
$31-40$ tahun & 14 & 41,2 \\
41-50 tahun & 14 & 41,2 \\
51-60 tahun & 5 & 14,7 \\
>60 tahun & 0 & 0 \\
Total & $\mathbf{3 4}$ & $\mathbf{1 0 0}$ \\
Pendidikan Terakhir & & \\
SMP & 0 & 0,0 \\
SMA & 0 & 0,0 \\
D3 & 0 & 0,0 \\
SI/D-IV & 30 & 88,2 \\
Magister (S2) & 4 & 11,8 \\
Total & $\mathbf{3 4}$ & $\mathbf{1 0 0}$ \\
Masa Kerja & & \\
<1 tahun & 0 & 0,0 \\
1-5 tahun & 12 & 35,3 \\
6-10 tahun & 12 & 35,3 \\
11-15 tahun & 2 & 5,9 \\
> 15 tahun & 8 & 23,5 \\
Total & $\mathbf{3 4}$ & $\mathbf{1 0 0}$ \\
\hline Sumb & &
\end{tabular}

Sumber : Data primer, 2020 (diolah)

Jenis kelamin secara umum dapat memberikan perbedaan pada perilaku seseorang. Dalam suatu bidang profesi jenis kelamin seringkali dapat menjadi pembeda aktivitas yang dilakukan oleh individu. Berdasarkan tabel 1 dapat diketahui bahwa responden dengan jenis kelamin laki-laki dan perempuan mempunyai jumlah yang berbeda dimana responden dengan jenis kelamin laki-laki sebanyak 10 responden $(29,4 \%)$, sedangkan responden dengan jenis kelamin perempuan sejumlah 24 responden (70,6\%). Berdasarkan data di atas bahwa guru dengan jenis kelamin laki-laki lebih sedikit jika dibandingkan dengan jenis kelamin perempuan hal ini disebabkan karena jurusan di SMK Dharma Wanita lebih membutuhkan tenaga perempuannya, sehingga dapat diartikan bahwa jenis kelamin guru sama-sama mempunyai peranan penting dalam proses pembelajaran. 
Usia dalam keterkaitannya dengan perilaku individu di lokasi kerja biasanya adalah sebagai gambaran akan pengalaman dan tanggung jawab individu. Berdasarkan tabel 1 di atas dapat diketahui bahwa untuk usia responden yang terbanyak 31-40 tahun dan usia 41-50 tahun yaitu sebanyak 14 responden (41.2\%), diikkuti dengan usia responden 31-40 tahun yaitu sebanyak 14 responden $(41,2 \%)$, untuk usia 51-60 tahun didapatkan data sebanyak 5 responden (14.7), sedangkan usia 21-30 tahun sebanyak 1 responden (2.9\%). Berdasarkan data di atas menunjukkan bahwa mayoritas guru berusia 31-40 tahun dan 41-50 tahun dan tergolong sebagaian besar berusia produktif, dan usia yang sangat mempunyai pengalaman menjadi guru.

Pendidikan seringkali dipandang sebagai salah satu kondisi yang mencerminkan kemampuan seseorang. Berdasarkan tabel 1 menunjukkan bahwa jumlah responden yang terbanyak adalah dari kelompok responden yang berpendidikan S1/D-IV yaitu sebanyak 30 responden (88.2\%) dari jumlah responden. Untuk responden tingkat Pendidikan S2 sebanyak 4 responden (11.8\%). Hal ini menunjukkan bahwa guru mayoritas sudah berpendidikan terakhir minimal S1/D-IV, dan sudah sesuai dengan peraturan perundang-undangan tentang guru, dimana seorang guru minimal Pendidikan terakhir adalah S1/D-IV.

Berdasarkan karakteristik responden menurut lama masa kerja sebagai seorang guru di SMK Dharma Wanita Gresik dapat dilihat pada tabel 1. Berdasarkan dari tabel di atas menunjukkan bahwa responden yang paling banyak adalah responden dengan masa kerja 1-5 tahun dan 6-10 tahun dengan jumlah responden sebanyak 12 responden $(35.3 \%)$, untuk responden denga masa kerja $>15$ tahun sebanyak 8 responden (23.5\%), dan untuk masa kerja 11-15 tahun sebanyak 2 responden (5.9\%). Hal ini membuktikan bahwa sebagian besar guru masih loyalitas terhadap sekolah untuk pengabdian diri menjadi seorang guru untuk meningkatkan kinerjanya.

2. Uji Validitas, Reliabilitas, Asumsi Klasik

Langkah pertama yang harus dilakukan adalah melakukan uji validitas dan reliabilitas.

a. Uji Validitas

Uji validitas digunakan untuk mengukur sah atau valid tidaknya suatu kuesioner. Suatu kuesioner dikatakan valid jika pertanyaan pada kuesioner 
mampu untuk mengungkapkan sesuatu yang akan diukur oleh kuesioner tersebut (Imam Ghozali, 2013). Jadi validitas ingin mengukur apakah pertanyaan atau pernyataan dalam kuesioner yang sudah dibuat betul-betul dapat mengukur apa yang hendak kita ukur. Cara yang digunakan adalah dengan analisa item, dimana setiap nilai yang ada pada setiap butir pertanyaan dikorelasikan dengan nilai total seluruh butir pertanyaan untuk suatu variabel dengan menggunakan rumus korelasi product moment. Uji signifikansi dilakukan dengan membandingkan nilai $r$ hitung dengan $r$ tabel untuk degree of freedom (df) $=n-2$, dalam hal ini $n$ adalah jumlah sempel. Pada penelitian ini jumlah sempel $(n)=34$ dan besarnya df dapat dihitung 34-2 $=32$, dengan df $=32$ dan alpha $=0.05 \mathrm{di}$ dapat $r$ tabel $=0,349$, sehingga syarat minimum untuk dianggap valid adalah nilai $r$ hitung $\geq 0,349$. Untuk menguji apakah masing-masing indikator valid atau tidak, bisa dilihat dari tampilan output Combach Alpha pada kolom Correlated ItemTotal Correlation bandingkan dengan hasil perhitungan $r$ table $=0,349$ (Imam Ghozali, 2013: 53). Tingkat kevalidan indikator atau kuesioner dapat ditentukan, apabila $r_{\text {hitung }}>r_{\text {tabel }}=$ Valid, dan $r$ hitung $<r_{\text {tabel }}=$ Tidak Valid. Hasil validitas selengkapnya dapat dilihat pada tabel berikut :

Tabel 2 Hasil Validitas Dengan Pembanding r Hitung dan $r$ Tabel

\begin{tabular}{|c|c|c|c|c|}
\hline Variabel & Indikator & r hitung & $r$ tabel & Keterangan \\
\hline \multirow{15}{*}{$\begin{array}{c}\text { Motivasi } \\
\text { (X2) }\end{array}$} & $\mathrm{X} 11$ & 0,712 & \multirow{15}{*}{0,349} & Valid \\
\hline & $\mathrm{X} 12$ & 0,686 & & Valid \\
\hline & $\mathrm{X} 13$ & 0,437 & & Valid \\
\hline & $\mathrm{X} 14$ & 0,879 & & Valid \\
\hline & $\mathrm{X} 15$ & 0,657 & & Valid \\
\hline & $\mathrm{X} 16$ & 0,783 & & Valid \\
\hline & $\mathrm{X} 17$ & 0,764 & & Valid \\
\hline & $\mathrm{X} 18$ & 0,695 & & Valid \\
\hline & $\mathrm{X} 19$ & 0,734 & & Valid \\
\hline & $\mathrm{X} 110$ & 0,422 & & Valid \\
\hline & $\mathrm{X} 111$ & 0,878 & & Valid \\
\hline & $\mathrm{X} 112$ & 0,650 & & Valid \\
\hline & $\mathrm{X} 113$ & 0,583 & & Valid \\
\hline & $\mathrm{X} 114$ & 0,715 & & Valid \\
\hline & $\mathrm{X} 115$ & 0,822 & & Valid \\
\hline \multirow{3}{*}{$\begin{array}{c}\text { Disiplin } \\
\text { Kerja }\end{array}$} & $\mathrm{X} 21$ & 0,664 & \multirow{3}{*}{0,349} & Valid \\
\hline & $\mathrm{X} 22$ & 0,749 & & Valid \\
\hline & $\mathrm{X} 23$ & 0,809 & & Valid \\
\hline
\end{tabular}




\begin{tabular}{|c|c|c|c|c|}
\hline \multirow{9}{*}{ (X3) } & $\times 24$ & 0,715 & & Valid \\
\hline & $\times 25$ & 0,876 & & Valid \\
\hline & X26 & 0,622 & & Valid \\
\hline & X27 & 0,607 & & Valid \\
\hline & X28 & 0,728 & & Valid \\
\hline & X29 & 0,752 & & Valid \\
\hline & $\times 210$ & 0,779 & & Valid \\
\hline & X211 & 0,717 & & Valid \\
\hline & $\mathrm{X} 212$ & 0,883 & & Valid \\
\hline \multirow{14}{*}{ Kinerja } & $\mathrm{Y1}$ & 0,482 & \multirow{14}{*}{0,349} & Valid \\
\hline & Y2 & 0,867 & & Valid \\
\hline & Y3 & 0,666 & & Valid \\
\hline & $\mathrm{Y4}$ & 0,648 & & Valid \\
\hline & $Y 5$ & 0,548 & & Valid \\
\hline & Y6 & 0,868 & & Valid \\
\hline & Y7 & 0,669 & & Valid \\
\hline & Y8 & 0,721 & & Valid \\
\hline & Y9 & 0,719 & & Valid \\
\hline & Y10 & 0,602 & & Valid \\
\hline & $\mathrm{Y} 11$ & 0,655 & & Valid \\
\hline & Y12 & 0,720 & & Valid \\
\hline & Y13 & 0,876 & & Valid \\
\hline & Y14 & 0,864 & & Valid \\
\hline
\end{tabular}

\section{Sumber : Data primer, 2020 (diolah)}

Dari tabel 2 hasil uji validitas di atas memperlihatkan nilai $r$ hitung setiap indikator variabel motivasi, disiplin kerja dan kinerja lebih besar dibanding nilai $r$ tabel $\left(r_{\text {hitung }}>r_{\text {tabel }}\right)$. Dengan demikian indikator atau kuesioner yang digunakan oleh masing-masing variabel motivasi, disiplin kerja dan kinerja dinyatakan valid untuk digunakan sebagai alat ukur variabel.

b. Uji Reliabilitas

Uji reliabilitas adalah alat untuk mengukur suatu kuesioner yang merupakan indikator dari variabel atau konstruk. Suatu kuesioner dikatakan reliabel atau handal jika jawaban seseorang terhadap pernyataan adalah konsisten atau stabil dari waktu ke waktu (Imam Ghozali, 2013). Pengukuran reliabilitas dapat dilakukan dengan cara one shott atau pengukuran sekali saja, dimana pengukurannya hanya sekali dan kemudian dibandingkan dengan pernyataan lain atau mengukur korelasi antar jawaban pertanyaan. SPSS memberikan fasilitas untuk mengukur reliabilitas dengan uji statistik Cronbach 
Alpha ( $\alpha$ ). Suatu konstruk atau variabel dikatakan reliabel jika memberikan nilai Conbach Alpha > 0,700 (Imam Ghozali, 2013). Hasil uji reliabilitas selengkapnya dapat dilihat pada tabel berikut ini:

Tabel 3 Hasil Reliabilitas

\begin{tabular}{lccc}
\hline \multicolumn{1}{c}{ Variabel } & $\begin{array}{c}\text { Cronbach's } \\
\text { Alpha }\end{array}$ & $\begin{array}{c}\text { Standar } \\
\text { Reliabilitas }\end{array}$ & Keterangan \\
\hline Motivasi (X1) & 0,939 & 0,700 & Reliabel \\
Disiplin Kerja (X2) & 0,941 & 0,700 & Reliabel \\
Kinerja (Y) & 0,939 & 0,700 & Reliabel \\
\hline
\end{tabular}

Sumber : Data primer, 2020 (diolah)

Nilai cronbach's alpha semua variabel motivasi, disiplin kerja, dan kinerja lebih besar dari 0,700, sehingga dapat disimpulkan indikator atau kuesioner yang digunakan variabel motivasi, disiplin kerja, dan kinerja semua dinyatakan handal atau dapat dipercaya sebagai alat ukur variabel.

c. Uji Asumsi Klasik

1) Uji Normalitas

Uji normalitas adalah untuk menguji apakah di dalam model regresi, varaibel independent dan variabel dependen keduanya memiliki distribusi normal atau tidak. Model regresi yang baik seharusnya memiliki analisis grafik dan uji statistic. Menurut Imam Ghozali (2013) menyatakan bahwa pengujian normalitas pada penelitian ini yaitu menggunakan uji non-parametrik Kolmogorof-Smirnov (K-S, dasar yang digunakan dalam pengambilan keputusan yaitu melihat dari angka atau nilai probabilitas dengan ketentuan sebagai berikut :

a) Dinyatakan terdistribusi secara normal, apabila nilai signifikansi atau nilai probabilitas $>0,05$

b) Dinyatakan tidak terdistribusi normal, apabila nilai signifikansi atau nilai probabilitas $<0,05$. 
Tabel 4. Uji Normalitas

\begin{tabular}{|c|c|c|}
\hline One-Sample & Imogorov-Smi & $\begin{array}{l}\text { Unov Test } \\
\text { Unstandardized } \\
\text { Residual }\end{array}$ \\
\hline $\mathrm{N}$ & & 34 \\
\hline \multirow[t]{2}{*}{ Normal Parameters ${ }^{a, b}$} & Mean & .0000000 \\
\hline & Std. Deviation & .23289470 \\
\hline Most Extreme & Absolute & .091 \\
\hline \multirow[t]{2}{*}{ Differences } & Positive & .079 \\
\hline & Negative & -.091 \\
\hline Test Statistic & & .091 \\
\hline Asymp. Sig. (2-tailed) & & $.200^{\mathrm{c}, \mathrm{d}}$ \\
\hline
\end{tabular}

Berdasarkan perhitungan uji normalitas didapatkan hasil nilai sig untuk unstandardized lebih besar daripada nilai probabilitas $(0,200>0,05)$. Dengan demikian dapat dinyatakan bahwa data berdistribusi normal karena nilia signifikansi lebih besar dari 0,05 (>0,05).

2) Uji Heteroskedastisitas

Uji heteroskedastisitas digunakan untuk mengetahui apakah terhadap ketidaksamaan varians dari residual satu pengamatan ke pengamatan lain. Model regresi yang memenuhi persyaratan yakni terdapat kesamaan varian dari residual satu pengamatan ke pengaatan yang lain tetap atau disebut heteroskedastisitas. Pengujian heteroskedastisitas dilakukan dengan menggunakan korelasi spermen, dasar yang digunakan dalam pengambilan keputusan yaitu melihat dari angka probabilitas denga ketentuan, sebagai berikut :

a) Dinyatakan tidak ada heteroskedastisitas apabila nilai signifikansi atau nilai probabilitas $>0,05$

b) Dinyatakan data ada heteroskedastisitas apabila nilai signifikansi atau nilai probabilitas $<0,05$. 
Tabel 5. Uji Heteroskedastisitas

\begin{tabular}{|c|c|c|c|c|c|}
\hline \multicolumn{6}{|c|}{ Correlations } \\
\hline & & & Motivasi & $\begin{array}{l}\text { Disiplin } \\
\text { Kerja }\end{array}$ & $\begin{array}{l}\text { Unstandardized } \\
\text { Residual }\end{array}$ \\
\hline \multirow[t]{9}{*}{$\begin{array}{l}\text { Spearman' } \\
\text { s rho }\end{array}$} & Motivasi & $\begin{array}{l}\text { Correlation } \\
\text { Coefficient }\end{array}$ & 1.000 & $.890^{* *}$ & -.032 \\
\hline & & Sig. (2-tailed) & & .000 & .858 \\
\hline & & $\mathrm{N}$ & 34 & 34 & 34 \\
\hline & Disiplin Kerja & $\begin{array}{l}\text { Correlation } \\
\text { Coefficient }\end{array}$ & $.890^{* *}$ & 1.000 & -.029 \\
\hline & & Sig. (2-tailed) & .000 & & .871 \\
\hline & & $\mathrm{N}$ & 34 & 34 & 34 \\
\hline & $\begin{array}{l}\text { Unstandardized } \\
\text { Residual }\end{array}$ & $\begin{array}{l}\text { Correlation } \\
\text { Coefficient }\end{array}$ & -.032 & -.029 & 1.000 \\
\hline & & Sig. (2-tailed) & .858 & .871 & \\
\hline & & $\mathrm{N}$ & 34 & 34 & 34 \\
\hline
\end{tabular}

${ }^{* *}$. Correlation is significant at the 0.01 level (2-tailed).

Sumber : Data primer, 2020 (diolah)

Berdasarkan hasil pengujian heteroskedastisitas dengan menggunakan korelasi Sperman dapat dilihat bahwa nilai signifikansi untuk variabel motivasi tidak memiliki korelasi yang signifikan dengan unstandardized residual karena nilai sig. $(0,858)>0,05$. Begitu juga dengan variabel disiplin kerja tidak memiliki korelasi yang signifikan dengan unstandardized residual karena nilai sig. $(0,871)>0,05$. Jadi dapat disimpulkan bahwa tidak terjadi masalah heteroskedastisitas dalam model regresi.

3) Uji Multikollinearitas

Uji multikolinearitas adalah untuk melihat ada atau tidaknya korelasi yang tinggi antara variabel bebas dalam satu model regresi linear berganda. Jika ada korelasi yang tinggi diantara variabel bebasnya, maka hubungan antara variabel bebas terhadap variabel terikatnya menjadi terganggu. Untuk mendeteksi multikolinearitas menggunakan metode Variance Inflation Factor (VIF) dan Tolerance (TOL). Dasar yang digunakan untuk pengambilan keputusan yaitu melihat dari nilai VIF, jika VIF melebih angka 10 maka bisa disimpulkan ada multikolinearitas. Selain itu juga dapat dilihat dari nilai TOL dimana jika nilai TOL semakin mendekati nilai 0 maka diduga ada multikolinearitas dan sebaliknya jika nilai TOL semakin mendekati 1 maka diduga tidak ada multikolinearitas. 
Tabel 6. Uji Multikolinearitas

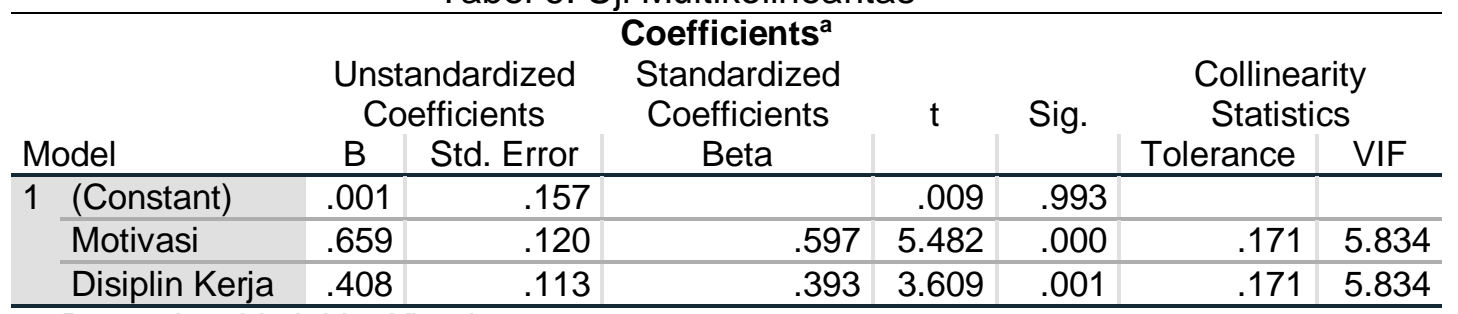

a. Dependent Variable: Kinerja

Sumber : Data primer, 2020 (diolah)

Berdasarkan hasil perhitungan, terlihat nilai tolerance berada di atas nilai 0,10 dan nilai VIF berada di bawah 10 sehingga dapat disimpulkan dari hasil perhitungan uji statistik dinyatakan tidak terhadai masalah multikolinearitas dalam model regresi.

3. Analisis Regresi Linear Berganda

1) Koefisien Regresi

Analisis regresi digunakan untuk mengji hipotesis tentang pengaruh secara parsial variabel bebas terhadap variabel terikat. Berdasarkan estimasi regresi berganda dengan menggunakan SPSS 26.0 diperoleh hasil seperti pada tebel berikut:

Tabel 4 Tabulasi Nilai Hasil Analisis Regresi Linear Berganda

\begin{tabular}{clcccc}
\hline \multicolumn{1}{c}{ Model } & $\begin{array}{c}\text { Unstrandardized } \\
\text { Coefficients }\end{array}$ & $\begin{array}{c}\text { Standardized } \\
\text { Coefficients }\end{array}$ & t hitung & Sig. \\
\hline b0 & : Konstanta & .001 & & .009 & .993 \\
b1 & : Motivasi (X1) & .659 & .597 & 5.482 & .000 \\
b2 & : Disiplin Kerja (X2) & .408 & .393 & 3.609 & .001 \\
\hline
\end{tabular}

R square : 0,937

Sumber : Data primer, 2020 (diolah)

Sesuai dengan model analisis yang digunakan, yaitu regresi linier berganda, maka dapat dilakukan analisis dengan rumus umum :

$$
\begin{aligned}
& Y=b_{0}+b_{1} \cdot X 1+b_{2} \cdot X 2+e \\
& Y=0,001+0,659 \cdot X_{1}+0,408 \cdot X_{2} \\
& \text { Dimana : } \\
& \mathrm{Y}=\text { Kinerja } \\
& \mathrm{b}_{0} \quad=\text { Konstanta } \\
& \mathrm{X} 1=\text { Motivasi } \\
& \text { X2 = Disiplin Kerja } \\
& b_{1} \cdot b_{2}=\text { Koefisien Regresi } \\
& \mathrm{e}=\text { Variabel pengganggu }
\end{aligned}
$$


2) Koefisien Determinasi $\left(R^{2}\right)$

Koefisien determinasi merupakan besaran yang menunjukkan kemampuan variabel independen dalam menerangkan variabel dependen, dengan kata lain, koefisien determinasi digunakan untuk mengukur seberapa jauh variabel-variabel bebas dalam menerangkan variabel terikatnya. Nilai koefisien determiasi ditentukan dengan nilai $R$ Square sebagaimana dapat dilihat pada tabel berikut :

Tabel 7 Koefisien Determinasi

Model Summary ${ }^{b}$

\begin{tabular}{|l|r|r|r|r|}
\hline Model & $\mathrm{R}$ & R Square & $\begin{array}{c}\text { Adjusted R } \\
\text { Square }\end{array}$ & $\begin{array}{c}\text { Std. Error of } \\
\text { the Estimate }\end{array}$ \\
\hline 1 & $.968^{\mathrm{a}}$ & .937 & .933 &, 24029 \\
\hline
\end{tabular}

a. Predictors: (Constant), Disiplin Kerja, Motivasi

b. Dependent Variable: Kinerja

Sumber : Data primer, 2020 (diolah)

Hasil perhitungan regresi dapat diketahui bahwa koefisien determinasi $\left(R^{2}\right)$ yang diperoleh sebesar 0.937 . Hal ini berarti $93,7 \%$ variasi variabel kinerja dapat dijelaskan oleh variabel motivasi dan disiplin kerja, sedangkan sisanya $(100 \%-93,7 \%)$ yaitu sebesar $6,3 \%$ diterangkan oleh variabel lain yang tidak diajukan dalam penelitian ini. Hal tersebut menunjukkan bahwa motivasi $\left(X_{1}\right)$, dan disiplin kerja $\left(X_{2}\right)$ mampu memberikan kontribusi terhadap variabel kinerja $(\mathrm{Y})$ guru SMK Dharma Wanita Gresik.

d. Uji hipotesis

1) Uji Signifikansi Parameter Bersama-sama / Simultan (Uji Statistik F)

Dalam menganalisa pengaruh motivasi dan disiplin kerja terhadap kinerja karyawan guru SMK Dharma Wanita Gresik serta untuk menguji dan membuktikan kebenaran atas hipotesis penelitian yang diajukan, maka hal tersebut dapat diketahui dengan cara melakukan penganalisaan data dengan uji signifikansi simultan (uji statistik F). Proses ini dilakukan dengan menggunakan bantuan software statistik SPSS (Statistical Program for Social Sciences) 26 for Windows Version. Berdasarkan dari hasil analisis dengan menggunakan program SPSS maka diperoleh hasil regresi sebagai berikut : 
Tabel 8 Hasil Uji Signifikansi Parameter Simultan (Uji Statistik F)

ANOVA $^{\mathrm{a}}$

\begin{tabular}{|l|r|r|r|c|c|}
\hline Model & Sum of Squares & \multicolumn{1}{c|}{ df } & Mean Square & $\mathrm{F}$ & Sig. \\
\hline 1 Regression & 26.646 & 2 & 13.323 & 230.742 & $.000^{\mathrm{b}}$ \\
Residual & 1.790 & 31 & .058 & & \\
Total & 28.436 & 33 & & & \\
\hline
\end{tabular}

a. Dependent Variable: Kinerja

b. Predictors: (Constant), Disiplin Kerja, Motivasi

Sumber : Data primer, 2020 (diolah)

Berdasarkan hasil pengujian hipotesis pada tabel 8 di atas diperoleh besarnya nilai signifikansi uji simultan (uji F) dengan nilai signifikansi sebesar 0.000 , dimana nilai signifikansi tersebut kurang dari $0.05(<0.05)$. Dengan demikian bahwa secara simultan variabel motivasi dan disiplin kerja berpengaruh signifikan terhadap kinerja guru SMK Dharma Wanita Gresik. Pada tabel 8 didapatkan hasil $F$ hitung dengan nilai sebesar 230.742 selanjutnya dibandingkan dengan hasil $\mathrm{F}$ tabel. Berdasarkan tabel distribusi $\mathrm{F}$ untuk kesalahan $5 \%$ dan $\mathrm{df}=2$, maka diperoleh $\mathrm{F}$ tabel $=3.29$ (Agus Widarjono, 2015). Dari data tersebud didapatkan bahwa nilai $F$ hitung lebih besar dari $F$ tabel sehingga secara simultan variabel bebas mempunyai pengaruh terhadap variabel terikat.

2) Uji Signifikansi Parameter Individual/Parsial (Uji Statistik t)

Untuk dapat menginterpretasikan koefisien variabel bebas (independen) dalam hal ini adalah variabel motivasi dan disiplin kerja dapat menggunakan unstrandardized coefficients maupun standardized coefficients. Analisa dilakukan berdasarkan dari nilai unstrandardized coefficients. Dalam hal ini tidak berdasarkan standardized coefficients karena apabila masing-masing koefisien variabel bebas (independen) kita standardisasi lebih dahulu, maka kita akan mempunyai koefisien yang berbeda karena garis regresi melewati origin (titik pusat) sehingga tidak ada konstantanya, sedangkan jika berdasarkan unstrandardized coefficients didapatkan nilai konstanta sebesar 0,001 . Proses ini dilakukan dengan menggunakan bantuan software statistik SPSS (Statistical Program for Social Sciences) 26 for Windows Version. 
Tabel 9 Hasil Uji Signifikansi Parameter Individual (Uji Statistik t)

Coefficients $^{\mathrm{a}}$

\begin{tabular}{|c|c|c|c|c|c|}
\hline \multirow[b]{2}{*}{ Model } & \multicolumn{2}{|c|}{$\begin{array}{l}\text { Unstandardized } \\
\text { Coefficients }\end{array}$} & \multirow{2}{*}{\begin{tabular}{|c|}
$\begin{array}{c}\text { Standardized } \\
\text { Coefficients }\end{array}$ \\
Beta \\
\end{tabular}} & \multirow[t]{2}{*}{$\mathrm{t}$} & \multirow[t]{2}{*}{ Sig. } \\
\hline & $\mathrm{B}$ & Std. Error & & & \\
\hline $\begin{array}{ll}1 \text { (Constant) } \\
\end{array}$ & .001 & .157 & & .009 & .993 \\
\hline Motivasi & .659 & .120 & .597 & 5.482 & .000 \\
\hline $\begin{array}{l}\text { Disiplin } \\
\text { Kerja }\end{array}$ & .408 & .113 & .393 & 3.609 & .001 \\
\hline
\end{tabular}

a. Dependent Variable: Kinerja

Sumber : Data primer, 2020 (diolah)

Dari kedua variabel independen yakni motivasi dan disiplin kerja yang dimasukkan kedalam model regresi, baik variabel motivasi dan disiplin kerja dapat dinyatakan signifikan. Hal ini dapat dilihat dari probabilitas signifikansi untuk motivasi sebesar 0.000 dengan nilai beta (B) sebesar 0.659 , karena nilai probabilitas signifikansi variabel motivasi kurang dari 0.05. Begitu juga dengan variabel disiplin kerja dapat dinyatakan bahwa variabel disiplin kerja berpengaruh terhadap kinerja, hal ini dapat dibuktikan dengan besarnya nilai signifikansi variabel disiplin kerja sebesar 0,001 dengan nilai beta 0,408 . Dari sini dapat disimpulkan bahwa secara parsial variabel kinerja dipengaruhi oleh variabel motivasi dan disiplin kerja. Hal ini juga didukung dengan penelitian sebelumnya dimana kepemimpinan dan siplin kerja memiliki pengaruh secara parsial terhadap efektifitas kerja karyawan PT. Erza Nusa Indonesia Gresik (Cahyadi, 2016). Dengan demikian bahwa variabel motivasi $\left(X_{1}\right)$ secara parsial berpengaruh signifikan terhadap kinerja $(\mathrm{Y})$, begitu juga dengan variabel disiplin kerja $\left(\mathrm{X}_{2}\right)$ secara parsial juga berberpengaruh terhadap kinerja (Y) guru SMK Dharma Wanita Gresik.

\section{E. Kesimpulan dan Saran}

1. Kesimpulan

a) Motivasi secara parsial berpengaruh signifikan terhadap kinerja guru SMK Dharma Wanita Gresik.

b) Disiplin kerja secara parsial berpengaruh signifikan terhadap kinerja guru SMK Dharma Wanita Gresik. 


\section{Vol : 5 Nomor : 2 September 2020}

\section{Saran}

a) Untuk mempertahankan dan meningkatkan kinerja dapat dilakukan melalui program pengawasan, serta membangun kerja sama tim yang baik dan penjelasan akan pentingnya arti disiplin terhadap pencapaian tujuan organisasi melalui kegiatan seperti outbond

b) Pimpinan hendaknya memberikan penghargaan untuk guru yang berprestasi dan memacu minat guru yang belum berprestasi untuk lebih giat dalam bekerja sehingga mereka juga akan mendapatkan penghargaan tersebut.

c) Atas keterbatasan penelitian ini, bagi peneliti selanjutnya disarankan menambah variabel bebas yang lainnya seperti kompensasi, budaya organisasi, komitmen organisasi, dan lingkungan kerja. Hal ini dengan pertimbangan bahwa variabel tersebut dapat langsung mempengaruhi kinerja guru.

\section{F. Daftar Pustaka}

a. Buku

Amir, Muhammad Faisal. 2015. Memahami Evaluasi Kinerja Karyawan Konsep dan Penilaian Kinerja di Perusahaan. Mitra Wacana Media : Jakarta

Edison, Emron. Anwar, Yohny. Komariyah, Imas. 2016. Manajemen Sumber Daya Manusia : Strategi dan Perubahan Dalam Rangka Meningkatkan Kinerja Pegawai dan Organisasi. Alfabeta : Bandung

Fahmi, Irham. 2016. Pengantar Manajemen Sumber Daya Manusia Kosep \& Kinerja. Mitra Wacana Media : Jakarta

Ghozali, Imam. 2009. Analisis Multivariate Lanjutan dengan Program SPSS. Badan Penerbit Unirversitas Diponegoro : Semarang

Ghozali, Imam. 2011. Aplikasi Analisis Mulitvariate dengan Program IBM SPSS 19. Badan Penerbit Unirversitas Diponegoro : Semarang

Ghozali, Imam. 2013. Aplikasi Analisis Mulitvariate dengan Program IBM SPSS 21 Update PLS Regresi. Badan Penerbit Unirversitas Diponegoro : Semarang

Hasibuan, Malayu S.P. 2016. Manajemen Sumber Daya Manusia Edisi Revisi. PT. Bumi Aksara : Jakarta

Hakim, Arif Rahman; Yahya, M. 2014. Analisis Pengaruh Gaya Kepemimpinan, Motivasi Kerja, dan Kompensasi Terhadap Kinerja Guru (Studi Kasus di SMA PPMI ASSALAM Surakarta). Jurnal Pendidikan Ilmu Sosial, Vol. 24, No. 1, Juni 2014. FKIP-UMS. Surakarta 
Vol : 5 Nomor : 2 September 2020

Moeheriono. 2012. Pengukuran Kinerja Berbasis Kompetensi Edisi Revisi. PT. RajaGrafindo Persada : Jakarta

Mulyadi. 2015. Manajemen Sumber Daya Manusia (MSDM). In Media : Bogor

Sobri, Jihad, Asep \& Charul Rochman (2009). Pengelolaan Pendidikan Yogyakarta: Multi Pressindo.

Sugiyono. 2014. Metode Penelitian Manajemen. Alfabeta : Bandung

Sutrisno. Edy. 2016. Manajemen Sumber Daya Manusia. Edisi Pertama. Cetakan Pertama. Jakarta : Penerbit Kencana

Wibowo. 2016. Manajemen Kinerja Edisi Kelima. PT. RajaGrafindo Persada : Jakarta

b. Jurnal

Cahyadi, Nur. 2016. Pengaruh Kepemimpinan Dan Disiplin Kerja Terhadap Efektivitas Kerja Karyawan Pt. Erza Nusa Indonesia Gresik. FIRM Journal Of Management Studies 1 (2). Universitas Presiden : Jakarta

Tanjung, Asridah. 2018. Pengaruh Kepemimpinan Kepala Sekolah, Motivasi Kerja dan Disiplin Kerja Terhadap Kinerja Guru (Study Pada Perguruan Muhammadiyah Setia Budi Pamulang). Jurnal Ekonomi Efektif Vol. 1, No. 1, Oktober 2018 (197207)

Malik, Abdul. 2013. Pengaruh Motivasi Kerja dan Kedisiplinan Terhadap Kinerja Guru SMA Assalam Surakarta dengan Kepemimpinan Kepala Sekolah Sebagai Variabel Moderasi. Jurnal manajemen Sumberdaya Manusia Vol. 7 No. 1 Juni 2013: 52-66 